\title{
Females Higher Education in Pakistan: An Analysis of Socio- Economic and Cultural Challenges
}

\author{
Sumara Mehmood \\ Master Degree Candidate in Higher Education, \\ School of Humanities and Social Sciences, \\ Dalian University of Technology China. \\ Li Chong \\ Vice Dean and Associate Professor \\ Graduate School of Education, \\ Dalian University of Technology China. \\ Mehmood Hussain \\ PhD Fellow \\ International Relations at School of International \& Public Affairs (SIPA), \\ Jilin University China.
}

\begin{abstract}
The developed nations around the world pay equal attention to male and female's higher education, however female's higher education in developing countries is most neglected sector, and same is true for Pakistan. Though the total enrollment in HEI's has increased from 0.276 million during 2001-02 to 1.298 million by 2014-15, but still Pakistan's GER in higher education was just 10\% during 2015-16. For instance female's enrollment has increased from $36.8 \%$ to $47.2 \%$ by 2014 , but the dream of gender equality in higher education is far away. Therefore, the present study is an effort to investigate the socio-economic and cultural challenges to female's higher education in Pakistan. To support the argument primary data had obtained through a survey feedback of 601 individuals across the country, and results explain that females are facing wide ranging socio-economic and cultural challenges during the attainment of higher education.
\end{abstract}

Keywords: Pakistan, Female's Higher Education, Socio-Economic and Cultural Challenges, Gender Discrimination, Coeducation

\section{INTRODUCTION}

In the era of rapid globalization and economic interdependence, higher education is considered a capital investment and is of paramount importance for socio-economic development of states. The higher education institutions for centuries had a fundamental role in producing professionals, scientists, political leaders, and economists, religious and social scholars, who serve the society to enrich its values and develop its resources. In the modern era young men and women equipped with higher education skills lead countries towards development and social justice. However, the problem with developing countries including Pakistan is that they have given low priority to higher education (Haider, 2008). The World Bank (2000) reported that developing countries will find it more difficult to benefit from the global knowledge-based economy if they fail to give relative importance to better higher education. 
Since the inception in 1947, state of higher education in Pakistan is not satisfactory and the sector is neglected by policy makers to develop a coherent policy to reform the education system. In Pakistan, Gross Enrollment Ratio (GER) in higher education was just 10\% during 2015-16, which is lower than many other developing countries in South Asia. For example, GER of India in higher education was $24 \%$, followed by $21 \%$ in Sri Lanka, $16 \%$ in Nepal and $13 \%$ in Bangladesh for same period. Though the enrollment of females in higher education has increased from $36.8 \%$ in 2001 to $47 \%$ by 2014 , but it is still far behind to catch gender parity (MFEPT, 2017). The country is spending only 2.7 percent share of its GNP on education as compared to 4 percent recommended by UNESCO for all developing countries.

It is worldwide acknowledgement that females equipped with higher education plays a significant role in building the human capital and the overall socio-cultural, and economic development of a country. Higher education empower females in two ways. It assist qualified females to become leaders in society and permit them to become role models for younger girls. At the same time, it help females to choose domains of expertise, whether this is as decision makers through influence on policy issues related to social, economic, and cultural development, or by their participation in family and community life (Pell, Winter 2015). Unfortunately education of females in Pakistan persistently neglected by society and state. The female literacy rate exposed that investment in human development tends toward favoring men over women. Females have limited opportunities to acquire higher education, professional and technical degrees. Thus, the gender inequality persistently increasing in education sector with passage of time.

The present study is intended to uncover the impacts of socio-economic and cultural challenges to female's higher education in Pakistan. The study is broken down in following sections. Section one is addressing the independence of females for travel in public transport, while the second section discuss the sexual harassment on campus and in public transport. The third section disclosed family support and opposition to female's higher education and the section four is addressing the socio-economic and cultural impediment in the way of female's higher education, and the final section is conclusion of the study.

\section{RESEARCH METHODOLOGY}

The study is supported by primary data which was gathered through a survey questionnaire. A structured questionnaire was prepared by the author, which was randomly distributed among male and female students through social media channels, such as Facebook, WhatsApp, and WeChat, as well as through email contacts. Altogether, 1,600 individuals were approached, however only 601 individuals returned the questionnaire with their valuable feedback, which explained in this study. 


\begin{tabular}{|c|c|c|c|}
\hline \multicolumn{4}{|c|}{ Demographic Details of Survey Participants } \\
\hline Respondents Nature & & $\mathbf{N}$ & $\%$ \\
\hline \multirow[t]{8}{*}{ Resident Province } & Islamabad & 25 & 4.2 \\
\hline & Punjab & 427 & 71 \\
\hline & Sindh & 36 & 6 \\
\hline & Khyber Pakhtunkhwa (KPK) & 67 & 11.1 \\
\hline & Baluchistan & 9 & 1.5 \\
\hline & Azad Jammu \& Kashmir (AJ\&K) & 18 & 3 \\
\hline & Gilgit Baltistan (GB) & 14 & 2.3 \\
\hline & FATA & 5 & 0.8 \\
\hline \multirow{2}{*}{ Gender } & Male & 601 & 52 \\
\hline & Female & 289 & 48 \\
\hline \multirow[t]{5}{*}{ Age } & Under 18 Years & 5 & 0.8 \\
\hline & 18-25 Years & 318 & 52.9 \\
\hline & 25-30 Years & 158 & 26.3 \\
\hline & 30-40 Years & 114 & 19 \\
\hline & $40+$ Years & 6 & 1 \\
\hline \multirow[t]{4}{*}{ Marital Status } & Single & 445 & 74 \\
\hline & Married & 144 & 24 \\
\hline & Divorced or Separated & 7 & 1.2 \\
\hline & Engaged/in a Relationship & 5 & 0.8 \\
\hline \multirow[t]{5}{*}{ Education } & 12 Years & 8 & 1.3 \\
\hline & 14 Years & 22 & 3.7 \\
\hline & 16 Years & 308 & 51.2 \\
\hline & 18 Years & 105 & 17.5 \\
\hline & 22 Years & 158 & 26.3 \\
\hline \multirow[t]{2}{*}{ Residential Area } & City & 328 & 54.8 \\
\hline & Village & 271 & 45.2 \\
\hline
\end{tabular}

\section{TRAVEL FREEDOM}

It has observed in previous studies that long distance of educational institutions hampered the higher study of females due to weak transportation system, travel cost, accompany costs, opportunity cost, physical costs and the cultural restrictions on the mobility of adolescent girls (Lina Song, 2006). In country like Pakistan with Islamic values and conservative traditions, the female's transportation to schools and universities become worse due to long distances, and risk of sexual harassment. Even though the higher educational institutions have setup their own transportation system for students but it is still unable to accommodate overcrowding students. Moreover, the university transport system only travel in urban centers and females from rural areas are traveling in public transport which is risky and more expensive.

Fig-1 Travel Freedom

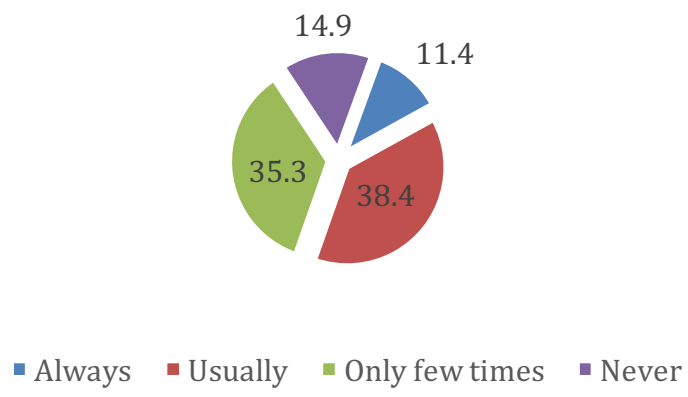

The authors put a question in front of survey participants about travel freedom during their higher education period. The fig 1, explain that 11.4 percent females were free to move from home to their higher education institutions, whereas 38.4 percent individuals experience usual 
freedom for travel. However, 35.3 percent participants enjoyed travel freedom only few times and another 14.9 percent females never went to higher educational institutions without a companion. Thus, the results exposed that females who are availing college and university transport are travelling alone, whereas females traveling in public transport accompanied by a family member, friend or a classmate.

Table-1.1 Cross Tab Analysis of Travel Freedom with Gender Variable

\begin{tabular}{cccccc}
\hline \hline Gender & Always & Usually & Only few times & Never & Total \\
\hline \hline Female studied/studying in Pakistan & 29 & 97 & 93 & 40 & 259 \\
Female studied/studying Abroad & 4 & 14 & 9 & 3 & 30 \\
Total & 33 & 111 & 102 & 43 & 289 \\
\hline \hline
\end{tabular}

The cross tab is a technique to quantify the opinions and views of different actors involved in a working relationship and their impacts on that particular work. We too employ this technique to judge the experience of travel freedom of females during studying in Pakistan and in foreign countries. Although, the survey participants studying in foreign countries are much lower than studying in Pakistan, but results exposed favorable opinions. The table-1.1 found that 289 females participated in the survey and only 33 females were identified who always enjoyed the freedom for travel, whereas 111 females reported that they usually travel without any companion. However, 102 individuals stated that they experienced few times freedom of travel for attending university/college, but 43 females admitted that they never enjoyed freedom to travel alone and always hangout with a companion.

\section{SEXUAL HARASSMENT}

Educational institutions are no longer the ivory tower of the past, however they have turned into arenas for sexual victimization. Since the early 1980s sexual harassment became common in schools, colleges and universities and the frequency of complaints have increased over the years. However, it is ignored by policy makers, law enforcement officers, and where it has been addressed, the focus has been on case based complaints (Leach, 2013). MacKinnon defined sexual harassment "the unwanted imposition of sexual requirements in the context of a relationship of unequal power. Central to the concept is the use of power derived from one social sphere to lever benefits or impose deprivations in another" (Joseph, 2015). The working women United Institute has also defined the sexual harassment in following words "verbal sexual suggestions or jokes, constant leering or ogling, accidentally brushing against your body, a friendly pat, squeeze, pinch or arm around you, catching you alone for a quick kiss, the explicit proposition backed by the threat of losing your job, and forced sexual relations" (WWUI, 1978).

Since the past few years sexual harassment has been observed in both the private and public sector universities in Pakistan. Reports revealed that senior teachers and heads of various departments of University of Peshawar have harassed female students (Ali M. , 2011). Another incident reported from International Islamic University Islamabad where faculty and administration was accused for sexual harassment of female students and junior female employees (Dempsey, 2012). A professor from Quaid-e-Azam University Islamabad harassed a female student when she visited his office for rectifying a mistake he had made in her marks sheet (Junaidi, 2014). Julie (2013) reported that sexual harassment has a significant psychological effects on the academic performance of female students and it negatively affect victim's health. It has been reported by female students that sexual harassment is major impediment to higher education in Pakistan (Ejaz Ashraf, 2015). They feel physical insecurity while traveling and studying with their male counterparts. Sometimes they experience sexual 
harassment from male students in educational institutions and during travel on public transport.

Table-2 Statement about Sexual Harassment

\begin{tabular}{|c|c|c|c|c|}
\hline Statement & $\begin{array}{l}\text { Strongly } \\
\text { Agree }\end{array}$ & Agree & Disagree & $\begin{array}{l}\text { Strongly } \\
\text { Disagree }\end{array}$ \\
\hline $\begin{array}{l}\text { Sexual harassment is major threat to female's higher } \\
\text { education } \\
\text { Female's face sexual harassment in public transport while }\end{array}$ & $21 \%$ & $\begin{array}{c}41.10 \\
\% \\
41.60\end{array}$ & $27.80 \%$ & $10.10 \%$ \\
\hline traveling alone & $26.80 \%$ & $\%$ & $22.60 \%$ & $9 \%$ \\
\hline
\end{tabular}

The table-2 discover the perceptions of females about sexual harassment in public transport and on campus. It is reported that $62.2 \%$ female individuals experienced sexual harassment during their higher education period. They stated that sexual harassment restrained them to go for higher education and most females decided to abandon higher education. Therefore, the major proportion of female participants were agreed with the threat of sexual harassment, which endorsed the results of earlier studies. Similarly, the second question was about sexual harassment in public transport. The 68.4 percent results unveiled that females are sexually harassed in public transport which is major transport source for rising middle class in the country and it is not safe for women's especially for female students.

\section{Fig-3 Actors in Sexual Harassment}

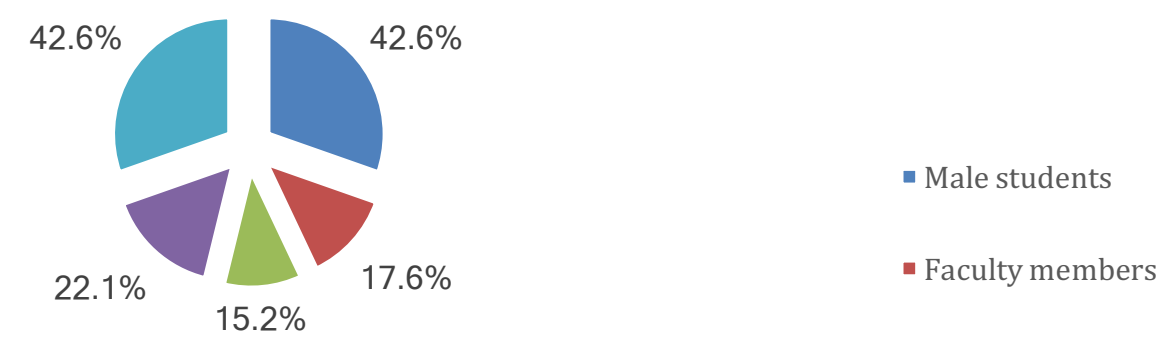

Females are harassed by a number of actors in the society. The identification of those evils is demanding attention from the researchers and policy makers. Therefore, the present study assumed the task to identify them and placed a question in front of survey participants. The 42.6 results in 'fig- 3 found that females are equally harassed by the male students, transport staff and male travelers in public transport. Whereas, the private coachers/tutors are also reported with 22.1 percent results. Similarly, on campus sexual harassment by the faculty members and administrative staff has also been identified with 17.6 and 15.2 percent results respectively. Thus, the above mentioned results are indicating alarming situation for female's higher education both in society and on campus. Females somehow are secure in universities and colleges as compared in the public transport but the evil of sexual harassment has not been eradicated completely. If it will not be addressed with an effective strategy, it will limit the enrollment of females in higher education institutions.

\section{FAMILY SUPPORT AND OPPOSITION TO FEMALES HIGHER EDUCATION}

Primarily support and opposition to females higher education comes from family. Cultural and political factors are secondary forces. After seventy years of journey as an independent state and integration with emerging globalization, Pakistan gradually changed its identity from highly religious and conservative country to liberal and moderate country for female's education. But, the conservative norms are still prevailing in remote areas of the country. 
Fig-4 Family Support

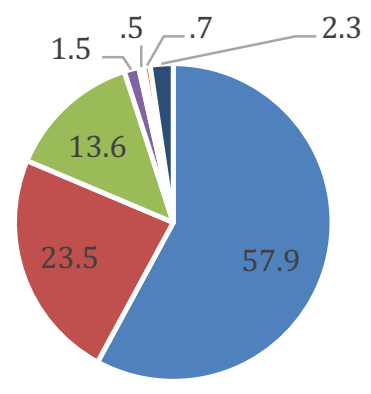

- Father

- Mother

- Elder

brother/sister

It is observed by earlier studies, that educated parents prefer their daughters to equip with higher education skills, whereas the illiterate and less educated parents impose restrictions on females education. The present study is based on data which was obtained from college and university graduates, and is a sign that their parents are definitely educated and care much about their children's education. The 'fig-4 explains that educated father, mother, and elder brother/sisters are advocating females higher education with 57.9, 23.5 and 13.6 percent results respectively. However, minimum support is reported from relatives and other family members such as uncles/aunties, grandparents and husbands.

\section{Fig-5 Family Opposition}

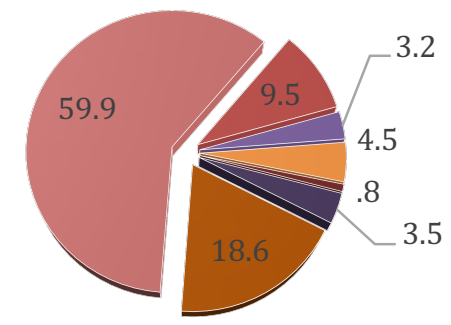

- Father - Mother "Elder brothers - Husband - Grand Parents " Relatives " None

Similarly, the family opposition is reported in Fig-5. The 59.9 percent results disclosed no opposition from family for female's higher education. However, only 13 percent parents dislike their daughter's enrollment in higher education. Similarly, 22.9 percent dissent is reported by the relatives, grandparents and husbands. Thus it is confirmed that opposition forces to females higher education not comes from the family but they belong to other than the family.

\section{SOCIO-CULTURAL CHALLENGES}

A limited faction of privileged class with enrollment of less than half a million have access to quality higher education at university level. Whereas, the lower and middle class repeatedly neglected to attain higher education due to various daunting challenges. Among them, females are further deprived to get higher education and literacy rate in females is 39.2 percent, which is lowest as compared to males. Low enrollment in higher education is an outcome of various factors; such as the high dropout rates at primary and secondary level, (Shah, 2005) conservative local culture and customs, poverty, sexual harassment, preference of boy's education over girls, lack of higher education institutions at local levels, and poor governance in universities etc. 
The world has gone under a tremendous scientific and technological revolution for the last half of the $20^{\text {th }}$ century. Particularly, invention of internet and adoption of personal computers during the last two decades have had a profound effect on the economic, social and even cultural development in modern society. Nations with logical thinking, reasoning and equipped with scientific skills can only survive in the $21^{\text {st }}$ century. The young netizens can acquire these skills through admission in a college or university. Unfortunately higher education in Pakistan has been most ignored sector since its independence in 1947 and is among the weakest in the modern nations (Leaping Forward, A Report on Higher Education in Pakistan, 2006). At present, less than 3\% of Pakistanis in the age group 17-24 are enrolled in a college/university as compared to $50-75 \%$ in developed nations. Similarly, at present 99\% Pakistani youth does not have access to higher education of international standards. Among them females higher education is most deprived sector in the country due to various socio-cultural challenges, and it failed to receive sympathy and attention from government and civil society to fix problems.

Economic factors always have considerable influence in education sector. Poor economic condition of countries and families restrain them to spend money on education which is a serious cause of low literacy rate. Pakistan is spending two percent of its GDP on education which is lowest in the region. The economy of the country is an agrarian and majority of the population is affiliated to agriculture to earn their livelihood. But, this industry is controlled by those landlords who have power both financial and political. They have restricted wealth in their own hands and pay inadequate wages to the poor workforce. This control leads towards the income inequality in vast majority of peoples settled in rural areas of the county. Therefore, the low income and scarcity of financial resources stem poor population to enroll their younger folks for proper education (Muhammad Zia Ullah Khan, 2015).

\title{
Feudalism
}

Since 1947, the country is hijacked by feudal lords and powerful elites, who have firm control over economic and political system. Feudalism is one important factor which is affecting education in Pakistan. It remain serious threat to promotion of education in the far off areas of the country, where majority of the rural masses are settled. There exist many instances where activists for education have been murdered on behest of the feudal lords of the area (Muhammad Zia Ullah Khan, 2015).

\section{Fig-6 Impacts of Feudalism}

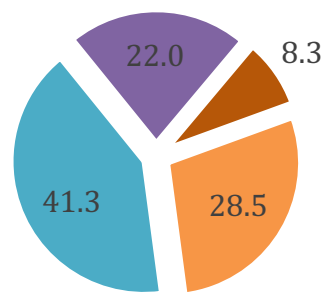

\author{
- Strongly Agree \\ - Agree \\ - Disagree \\ - Strongly Disagree
}

As literature specified that feudalism and its sub-forms such as Jagirdari and zamindari system constrained peasants to send their kids for education. It was utmost desire of the study to find out link between feudalism and poor performance of females in higher education. The 'Fig-6' gives an interesting information that 69.8 percent individuals view feudalism a major threat to female's higher education. However remaining participants of the study hold opposite views. Hence the study confirmed that feudalism is an ulcer of the society and it needs to prevent exploitation of peasants and their siblings. 
Table-6.1 Cross Tab Analysis of Impacts of Feudalism with Gender Variable

\begin{tabular}{|c|c|c|c|c|c|}
\hline Gender & Strongly Agree & Agree & Disagree & $\begin{array}{l}\text { Strongly } \\
\text { Disagree }\end{array}$ & Total \\
\hline Male & 89 & 120 & 74 & 29 & 312 \\
\hline $\begin{array}{c}\text { Female studied/studying } \\
\text { in Pakistan }\end{array}$ & 74 & 115 & 53 & 17 & 259 \\
\hline $\begin{array}{l}\text { Female studied/studying } \\
\text { Abroad }\end{array}$ & 8 & 13 & 5 & 4 & 30 \\
\hline Total & 171 & 248 & 132 & 50 & 601 \\
\hline
\end{tabular}

The Table 6.1 is explaining the perceptions of survey participants about feudalism and female's higher education. The 89 male respondents were strongly agree that feudalism restrain the way of female's higher education, as compared to 82 female individuals. Similarly, 120 male and 128 female individuals were agreed with negative consequences of feudalism on higher education. However, 74 male participants were of view that feudalism have no negative impacts on females higher education as compared to 58 female's participants. In sum, 210 out of 289 female individuals and 209 male participants reported feudalism as an impediment to empower females through higher education. The participants of the survey suggested authors that female's enrollment can improve after countering negative impacts of feudalism. So, it is duty of government and other concerned bodies to introduce and implement effective policies to delimit influence of feudalism in the country.

\section{Religious Misconception}

Universities in Pakistan are controlled by religious vigilantes whose job is to guard public morality- the Islami Jamiat-e-Talba and other Islamic groups are the wings of those religious bodies who are active in colleges and universities. They may not engage in debates or political discussions that may strain the patience of the guardians. They ban male-female gathering and assigned separate sections for male and female students in class rooms. Females are not allowed to take part in musical programs such as; drama, theater, poetry, and music concerts.

Orthodox Islamic groups in the country have considerable influence over general masses. Generally, Islamic clerks in the mosques and madrassas teach kids Quran and basic knowledge of Islam, and during the training cycle they develop close association with the parents. The poor and illiterate parents tend to enroll their children in Islamic madrassas where they only attain Quranic education and deprived from modern and scientific education. Mullahs in the mosque and madrassas misinformed parents that Islamic principles prohibit females to go outside for education, and they are supposed to perform household activities. As a result of their teachings, parents with poor educational background forbidden their daughters to enroll in educational institutions, which has increased the gender gap and give way for income and gender inequality (Hoodbhoy, 2006).

Fig-7 Role of Religious Misconception

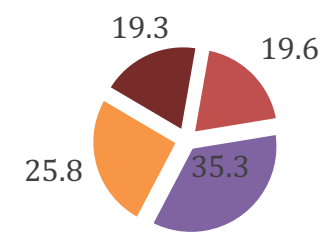

- Strongly Agree - Agree - Disagree - Strongly Disagree 
As discussed above religion is playing fundamental role in the society and state. Pakistan gained independence in the name of Islam and the founding fathers declared Islam as a state religion. Therefore, since then Islamic clerics occupied center stage in the society and whenever needed mold public behavior against the state. The Fig-7 uncovered the religious misconceptions in the way of female's higher education. The 54.9 percent results found that religious misconceptions restrict female's enrollment in higher education. They argue that teachings of orthodox Islamic scholars are increasing opposition in family and society for female's higher education as the large masses view coeducation a threat to their honor and religion.

Table-7.1 Cross Tab Analysis of Religious Misconception with Gender Variable

\begin{tabular}{cccccc}
\hline \hline Gender & Strongly Agree & Agree & Disagree & Dtrongly & Disagree \\
\hline Male & 54 & 108 & 81 & 69 & Total \\
$\begin{array}{c}\text { Female studied/studying } \\
\text { in Pakistan }\end{array}$ & 53 & 97 & 66 & 43 & 259 \\
$\begin{array}{c}\text { Female studied/studying } \\
\text { Abroad }\end{array}$ & 11 & 7 & 8 & 4 & 30 \\
Total & 118 & 212 & 155 & 116 & 601 \\
\hline \hline
\end{tabular}

While performing comparison analysis of male/female perceptions about religious misconception, it has examined in table 7.1 that 162 out of 312 male individuals argue that low enrollment of females in higher education is an outcome of religious misconceptions. Whereas, 167 out of 289 female respondents were of view that poor information about religion and influence of orthodox clerics constrained females to get higher education. The results exposed that around 55 percent survey participants withhold religion as factor for low enrollment of females in higher education. Therefore, it is need of hour to introduce new doctrine to minimize legacy of madrassa clerics through comprehensive state policy, and the government and other concerned agencies introduce strategic and effective programs for teaching religion with translation in local languages which not only increase the understanding about religion but will also remove the misconception. At the same time, it is necessary to increase numbers of training centers for illiterate parents and adults to counter exceeding illiteracy in elders.

\section{Non-Protective Environment, Lack of HEI's and Conservative Norms}

After examination of impact of feudalism and religion on female's higher education we moved on to investigate other social and cultural challenges to females and asked following questions to our survey participants.

Table-8 Socio-Cultural Challenges

\begin{tabular}{|c|c|c|c|c|}
\hline Statement & $\begin{array}{l}\text { Strongly } \\
\text { Agree }\end{array}$ & $\begin{array}{l}\text { Agr } \\
\text { ee }\end{array}$ & $\begin{array}{l}\text { Disagr } \\
\text { ee }\end{array}$ & $\begin{array}{l}\text { Strongly } \\
\text { Disagree }\end{array}$ \\
\hline $\begin{array}{l}\text { Parent's fear of non-protective environment restrain female's to } \\
\text { get higher education }\end{array}$ & 41.6 & 46.4 & 9.3 & 2.7 \\
\hline $\begin{array}{l}\text { Lack of local educational institutions pose major hurdle to female's } \\
\text { higher education }\end{array}$ & 33.8 & 44.6 & 18.1 & 3.5 \\
\hline $\begin{array}{l}\text { Conservative cultural customs restrict women to attain higher } \\
\text { education }\end{array}$ & 30.8 & 48.1 & 16.3 & 4.8 \\
\hline
\end{tabular}

Females in Pakistan are facing multilayer cultural and social challenges at different levels which seriously damage their personality, creativity, and productivity. The table-8 reported that 88 percent parents are reluctant to send their daughters for higher education due to nonprotective environment outside home. They are anxious for prevailing safety and violence against females in the society and prefer their daughters stay at home. Secondly, 78.4 percent 
respondent's claim that colleges and universities are located in urban vicinities which are far away from rural localities. Thus, the lack of higher educational institutions at the door step obstruct females to enroll for higher education. It is primary requirement of the time that government should establish new universities and colleges in towns and surrounding areas of rural vicinities where 55 percent population is residing.

Similarly, conservative cultural norms and values are marginalizing females to get higher education. Females are subordinated by male opponents in decision making regarding marriage, job and education. They are discouraged to work and harassed at work places. Parents prefer boy's education over girls and direct them to learn domestic chorus. The 78.9 percent results exposed severe impacts of local norms and values on female's higher education. These outdated cultural norms and customs occupied center stage in the society especially regarding female's higher education. Remote areas like Baluchistan province and FATA are administered by the local land lords and Jirga's, who have greater influence over local population, and despite hundred years of journey they continue to subjugate females.

Fig-9 Major Social Problems to Females Higher Education

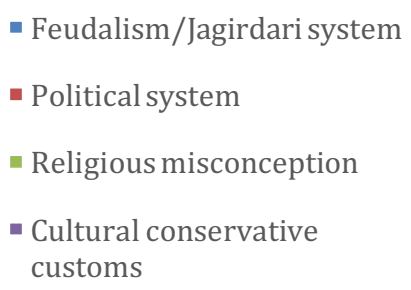

The state of higher education in female students is not satisfactory in Pakistan due to several reasons. Some earlier studies indicated that cultural norms keep the girls away from school. Likewise, others attributed the low school enrollment in rural Punjab to the cultural and religious norms of the society (Naimatullah Hashmi, 2008). By keeping in mind we placed a similar question to the survey participants about obstacles to female's higher education attainment. The results revealed interesting facts about challenges to female's higher education. The Fig-9 specified that cultural conservative customs secured first position with 45.4 percent results to keep the girls out from higher educational institutions. The second most influential factor is gender discrimination with 18 percent results which seriously damage girl's higher education. Similarly perception of threat to family honor in parents in case of girl's entrance in college or university added resentment for higher education with 12.3 percent results. The above results disclosed that Pakistani society still adhere to conservative customs with regard to female's empowerment, but if we want to grow society with equal rights and obligations then we should cope the influence of conservative customs on society. Secondly, it is duty of parents to give equal rights to their daughters for study as compared to their sons. After getting higher education and honorable job, girls can become productive members of the family and can extend helping hand to fight against poverty and economic deprivation.

\section{GENDER DISCRIMINATION}

Females' suffer gender discrimination as a consequence of the prevailing socio-cultural climate in Pakistan. Their status is significantly divided across classes, regions, and the rural/urban divide due to uneven socio-economic development and the influence of tribal, feudal, religious 
and social formations on women's lives. The country has generally a male dominating society, and commonly hold a hostile attitude towards women (Sen, 2001). It is noted, that gender discrimination is causing low enrollment rate of girls at primary level of education. The ratio of male and female participation is projected at the primary school in the shape of ratio of boys and girls as 10:4 respectively. Only 22 percent girls, as compared to 47 percent boys, complete primary schooling.

Additionally, female schooling is worse in Baluchistan with 32 percent compared to high urban male literacy rates (and 80 percent among the urban male in Sindh) (Mukhtar, 2012). Besides primary level schooling, gender discrimination is also abundant at higher education level. Females are regulated by family members, relatives and society to enroll in higher education due to insecure environment and coeducation system in universities. The universities are also causing low enrollment of female students by allocating more seats to male students than females. Gender inequality in Pakistani higher education system is a consequence of persistent discrimination at early stage education. Boys are far ahead in the provision of education and in the access to the schooling available. However, girls are tasked to learn domestic chorus and how to become good mothers and wives.

\section{Fig- 10 Gender Discrimination}

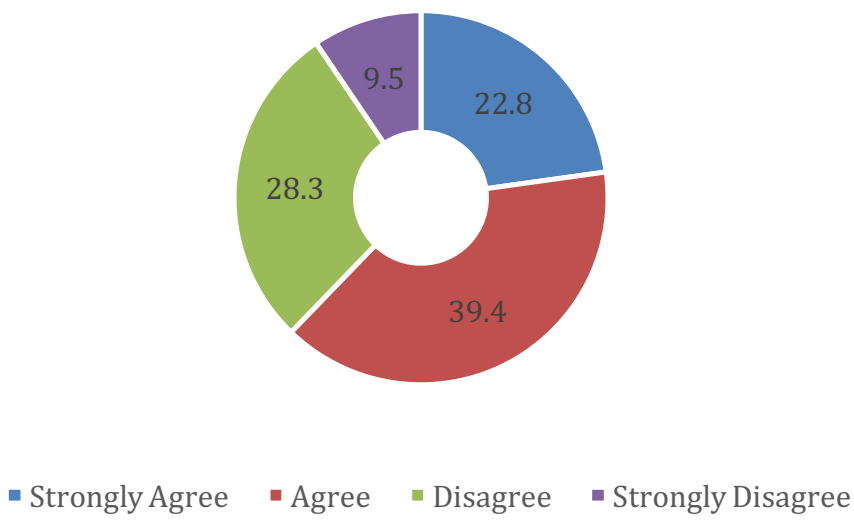

The Fig 10 reported that 62.2 percent individuals were agreed that gender discrimination is a key factor behind female's low enrollment in higher educational institutions. While, 37.8 percent individuals were disagreed with the view. However, the overall results are satisfactory to claim that low enrollment of females in higher education have connection with gender discrimination. But, if the gender discrimination effectively controlled there are bright prospects for higher enrollment of females in higher education.

Table-10.1 Comparative Analysis of Gender Discrimination with Gender Variable

\begin{tabular}{cccccc}
\hline \hline Gender & Strongly Agree & Agree & Disagree & Strongly \\
Disagree & Total \\
\hline \hline $\begin{array}{c}\text { Male } \\
\begin{array}{c}\text { Female studied/studying } \\
\text { in Pakistan }\end{array}\end{array}$ & 66 & 113 & 101 & 32 & 312 \\
$\begin{array}{c}\text { Female studied/studying } \\
\text { Abroad } \\
\text { Total }\end{array}$ & 62 & 112 & 64 & 21 & 259 \\
\hline \hline
\end{tabular}

It has examined in table-10.1 that 179 out 312 male individuals have positive opinions for gender discrimination in higher educational institutions. Similarly, 195 out of 289 female participants view that gender discrimination is major factor behind low literacy rates in 
females. Thus, the results prove that gender discrimination hinder the way of female's higher education and it need to fix in first instance.

\section{GIRLS EARLY SCHOOL DROP OUTS AND PREFERENCE OF BOY'S EDUCATION}

Pakistan is a signatory of international accord for 'Universal Primary Education for All' by 2015, and in this regard Islamabad has been assigned a target to achieve 100 percent primary school enrollment. However, at present the school enrollment stands at 70 percent, out of which 50 percent school going children aged between 5-9 years leave school prior to complete grade-V (NCHD, 2010). An overall dropout rate for both boys and girls is 50 percent in the country. Whereas, the dropout rate for girls is 56 percent as compared to 44 percent for boys (AEPAM, 2006-07). The situation of dropout rates for girls is more alarming in rural areas as compared to urban regions. It is alarming indicator that seven million out of 13 million out of school children are girls (SPARC, 2004).

The first and foremost factor is that parents show little or no interest in girl's education. Other factors are including; cultural constraints, high fees and poor economic conditions. Equally, parents illiteracy also play chief role in girl's higher dropouts. Illiterate parents are not interested to invest in girl's education as they view that investment in girl's education is a waste of money and resources as there is common view that boys will earn and therefore support the family financially after getting employment whereas parents do not see their girls working or bringing home any income once they leave home (Gulbaz Ali Khan, 2011).

Parents in Pakistan usually pay more attention to male children rather than female. They heavily invest on male providing them good education as compared to female children. The situation is even nastiest in rural areas of the country, where Islamic identity and social structure have greater impacts on gender inequality as we are living in male dominated society and females are not free to follow their wishes. Females need family support to get education while bearing the expenses of tuition fees, transportation facility etc. They are dependent on male members of the family for financial support and sometimes for physical safety (Muhammad Irfan Chani, 2011).

It is quite apparent that poverty is the dominant factor behind girls drop outs from school. The poor economic conditions of the parents often force them to remove girls from school and engage them in either domestic activities or make them work. Another reason behind girl's low enrollment in schooling is physical security and threat of sexual harassment, which increased anxiety in parents for girl's safety. Similarly, lack of availability of schools in local area, inadequate infrastructure, cultural and religious beliefs, social exclusion, low social positioning, low parental perception are obstructing girl's education (Ali R. E., 2005).

Girls in many developing and under-developed countries often have little choice about whom or when they marry. According to UNICEF assessment of 2005, among women ages 15 to 24, 48 percent were married before the age of 18 in South Asia, 42 percent in Africa, and 29 percent in Latin America. Early marriage curtails girl's freedom, isolates them from peers, and ends their education prematurely. More often they face sexual violence from their older partners, and are restricted to move freely (Greene, 2011). In Pakistan after marriage, girls are responsible to do domestic chorus, look after their in-laws, children and husband. Their marriage is considered as primary responsibility as compared to education. Therefore, early marriage practice in Pakistan seriously curtail girl's education and it needs to stop immediately with systematic approach from government and society (Fauzia Maqsood, 2012). 
Fig-11 Impacts of Early Marriage on Girls Education

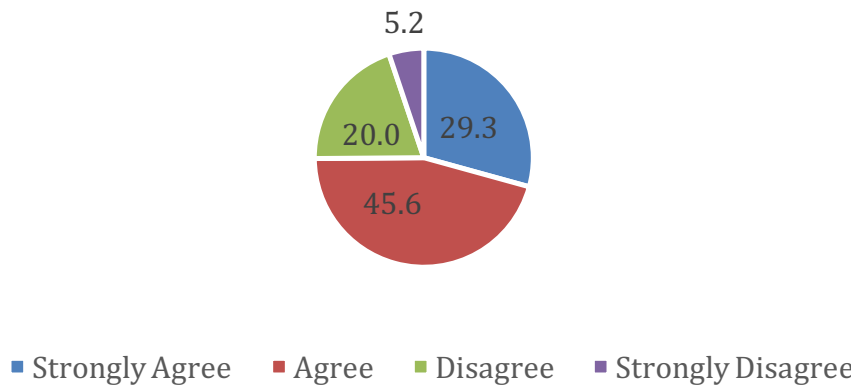

In Fig-11, it is recorded that early marriage have negative impacts on female's higher education in Pakistan. The study found that 74.9 percent individuals were fully agree that early marriage of girls stop them to get higher education, which is primary reason behind low literacy rates and gender inequality. If, state and society introduce new laws about female's age for marriage, there are bright chances to increase enrollment of females in higher educational institutions.

Fig-12 Reasons behind Girls Early Dropout from School
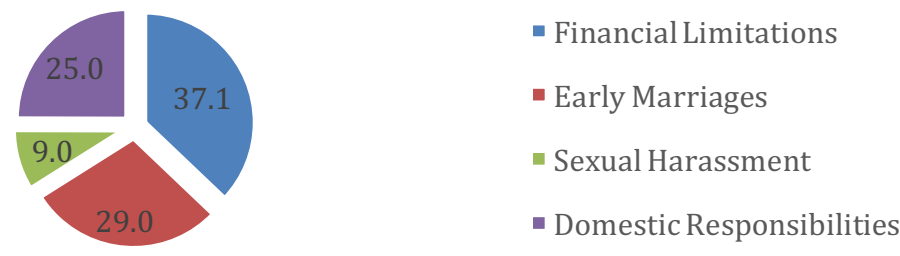

A similar question was put forward in front of survey participants to examine their views for reasons behind girl's early dropouts from school. The results in 'Fig-12' disclosed that poverty and lack of financial resources are primary reasons behind girl's early dropouts from school with 37.1 percent results. Whereas, early marriage is secondary factor with 29 percent results. However, sexual harassment is reported with 9 percent results and domestic responsibilities and chorus with 25 percent results.

Table-12.1 Cross Tab Analysis of factors behind Girls early school dropout with gender variable

\begin{tabular}{cccccc} 
Gender & $\begin{array}{c}\text { Financial } \\
\text { Limitations }\end{array}$ & $\begin{array}{c}\text { Early } \\
\text { Marriages }\end{array}$ & $\begin{array}{c}\text { Sexual } \\
\text { Harassment }\end{array}$ & $\begin{array}{c}\text { Domestic } \\
\text { Responsibilities }\end{array}$ & Total \\
\hline \hline $\begin{array}{c}\text { Male } \\
\text { Female }\end{array}$ & 104 & 91 & 34 & 83 & 312 \\
$\begin{array}{c}\text { studied/studying in } \\
\text { Pakistan } \\
\text { Female }\end{array}$ & 111 & 72 & 18 & 58 & 259 \\
$\begin{array}{c}\text { studied/studying } \\
\text { Abroad } \\
\text { Total }\end{array}$ & 8 & 11 & 2 & 9 & 30 \\
\hline \hline
\end{tabular}

The table-12.1 found that 104 out of 312 male respondents were of view that poverty and scarcity of financial resources obstruct the female's education and force them to leave school before completion of education. Similarly, 119 females have similar views about early dropouts. As far as, early marriage is concerned, 91 male and 83 females pointed out that early marriage of girls hamper their higher education aspirations. Moreover, 34 male and 20 female individuals view that sexual harassment also have negative impacts on girl's dropouts from school. It is investigated with the views of 83 male and 67 female individuals that domestic 
responsibilities are also among the factors. Through the comparative analysis of male and female perceptions it is concluded that poverty and limited economic resources force parents to abandon their daughter's education. Therefore, based on the facts, this study recommends that state and society should introduce some programs for financial support to deprived families, which will encourage them to enroll girls in school.

\section{Fig-13 Reasons behind Boy's Preference over Girl's Education}

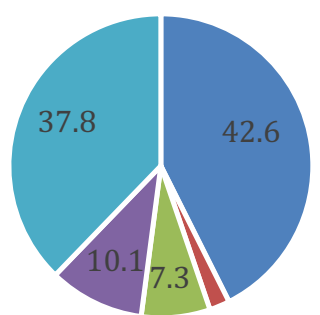

2.2

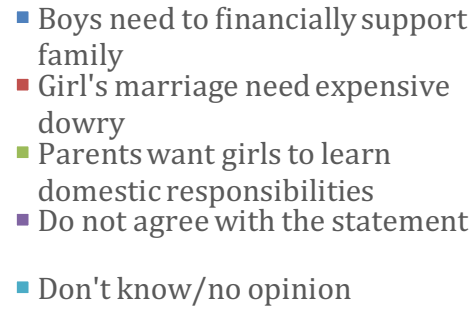

It was highly plausible to investigate that why parents prefer boy's education over their daughters. Thus the authors made an attempt to investigate key reasons, and Fig 13 exposed that 42.6 percent results fount that boy's productivity after getting higher education is chief reason.

\section{COEDUCATION AND FEMALE'S HIGHER EDUCATION}

Fauzia Maqsood et. al. argued that parents of female students perceive coeducation a major threat to family honor. As members of conservative society, families have mostly unfavorable attitude towards coeducation. They think that coeducation could have been bad influence on their daughter's socialization. Parents think after studying in coeducation system, no one will marry with their daughters which strongly influence to their opposition of education with boys (Fauzia Maqsood, 2012). It has been observed in literature that coeducation system limits enrollment of females in higher education, because most of the higher educational institutions have this system.

Table-14 Coeducation

\begin{tabular}{llllc} 
Statement & Strongly Disagree & Agree & Strongly Disagree & Disagree \\
\hline \hline Coeducation limits female's enrollment in higher education & 17.3 & 42.6 & 33.4 & 6.7 \\
Girls feel uncomfortableness in coeducation system & 13.8 & 31.3 & 45.4 & 9.5 \\
Coeducation is threat to family honor & 19.3 & 48.3 & 26.6 & 5.8 \\
\hline \hline
\end{tabular}

The present study is dedicated to purify existing literature by asking three distinct questions to the survey participants. The first question was asked about impacts of coeducation on female's enrollment. It has discovered in table-14 that 59.9 percent individuals identify that coeducation limit enrollment of females in higher education. Whereas, second question was about uncomfortableness of female students in coeducation and the results pointed out that 45.1 percent individuals see that females are not fitting in coeducation and face uncomfortable atmosphere. However 54.9 percent individuals were disagreed with the claim and argued that females have no feeling of uncomfortableness in coeducation and they adjust themselves in the system.

The third question was put forward by the researchers to monitor perceptions of threat to family honor while studying in coeducation. In response to question, 67.6 percent survey 
participants were agreed that their parents observe coeducation a major threat to family honor. Thus they oppose female's education in coeducation institution. It is examined here that question one and three have higher negative impacts on girl's higher education rather than question two which is dealing with their comfortableness in coeducation system. The results of question two revealed that girls have ability and willpower to adjust in a system where boys are studying. Whereas, another two questions are primarily addressing connections of parents and their daughters where girls have minimum autonomy to take independent decisions.

Table -15.1 Cross Tab Analysis with Gender Variable

Coeducation limits female's enrollment in higher education

\begin{tabular}{|c|c|c|c|c|c|c|c|}
\hline \multirow{2}{*}{$\begin{array}{l}\text { Gender } \\
\text { Male }\end{array}$} & \multirow[t]{2}{*}{ Strongly Agree } & \multicolumn{2}{|c|}{ Agree } & \multirow[t]{2}{*}{ Disagree } & Strongly Disagree & \multicolumn{2}{|c|}{ Total } \\
\hline & & 55 & 136 & & 98 & 23 & 312 \\
\hline Female & & 49 & 120 & & 103 & 17 & 289 \\
\hline Total & & 104 & 256 & & 201 & 40 & 601 \\
\hline \multicolumn{8}{|c|}{ Girls feel uncomfortableness in coeducation system } \\
\hline Gender & Strongly Agree & \multicolumn{2}{|c|}{ Agree } & Disagree & Strongly Disagree & \multicolumn{2}{|c|}{ Total } \\
\hline Male & & 40 & 93 & & 147 & 32 & 312 \\
\hline Female & & 43 & 95 & & 126 & 25 & 289 \\
\hline Total & & 83 & 188 & & 273 & 57 & 601 \\
\hline \multicolumn{8}{|c|}{ Coeducation is threat to family honor } \\
\hline Gender & Strongly Agree & \multicolumn{2}{|c|}{ Agree } & Disagree & Strongly Disagree & \multicolumn{2}{|c|}{ Total } \\
\hline Male & & 70 & 152 & & 71 & 19 & 312 \\
\hline Female & & 46 & 138 & & 89 & 16 & 289 \\
\hline Total & & 116 & 290 & & 160 & 35 & 601 \\
\hline
\end{tabular}

It is quite interesting to explain views of male and female individuals about impacts of coeducation on female's higher education. The table-15.1 noted that 191 male participants hold views that coeducation is limiting enrollment of females in higher education, as compared to 169 female participants. Similarly, 133 out of 312 male individuals pointed out that females face difficulty to adjust in coeducation system as compared to 138 female participants. Whereas, the 222 out of 312 male individuals argued that female's education in coeducation system is a threat to family honor. The higher ratio of male individuals is alarming that despite attaining higher education, males still hold conservative attitude regarding female's education in coeducation system. However, it is also interesting to demonstrate here that 184 out of 289 females hold similar views about link between family honor and coeducation. Therefore, in total 406 individuals from both segments of the society reported that coeducation is posing threat to family honor and urge state and society to take appropriate measures. This study suggest that threat regarding the coeducation could be mitigate through awareness of masses in society and this target could be achieved through providing equal rights and justice to girls in family and society.

In the above paragraphs we have discussed coeducation system and enrollment of females in higher education, however below we have asked a question to judge family support for female's higher education. 


\section{Fig-16 Family Support for Coeducation System}

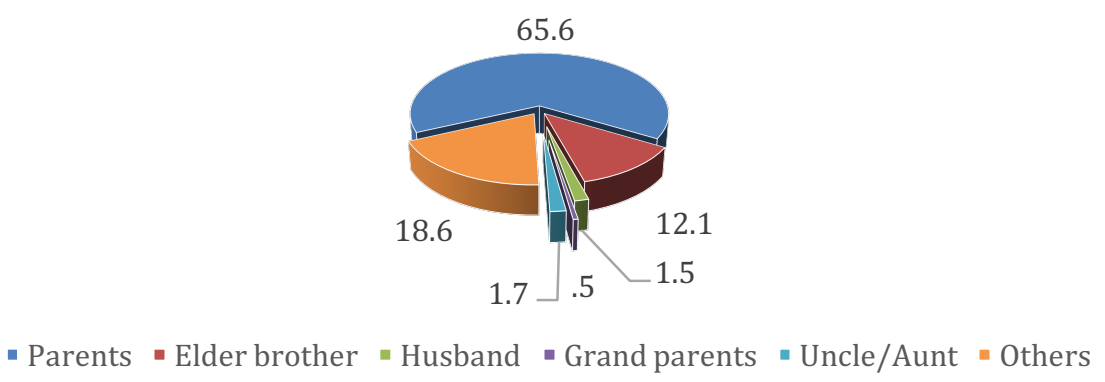

In Fig-16 it is examined that parents of 65.6 percent individuals support female's enrollment in coeducation system, while a tiny proportion of 12.1 is pointing out support from elder brothers for coeducation. Moreover, other segments of society are also encouraging females to get higher education in coeducation atmosphere. Thus, the above results found that if parents are agree to enroll their daughters in coeducation system, other members of the society fail to lodge resistance against female's education in coeducation.

Fig-17 Family Opposition for Coeducation System

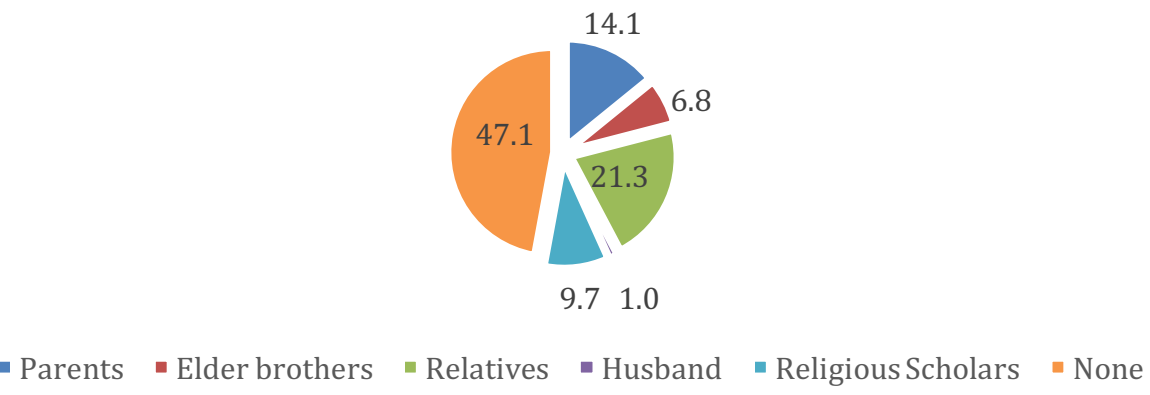

The Fig-17 examined that opposition for female's education in coeducation comes from the relatives as compared to parents. Pakistan is a country where joint family system is still existing where uncles and aunties are living together. The 21.3 percent results of the survey pointed out that uncles and aunties are assuming that interference in the matters of female's education is their appropriate right and they often use it. However, it is observed that only 14.1 percent parents are oppose to female's education in coeducation system as compared to 6.8 and 1 percent opposition faced by elder brothers and husbands respectively. Moreover it is interesting to quote here resentment of mullahs and religious scholars with 9.7 percent results, however they are most influential in rural vicinities where majority of the illiterates are residing. However, it is exciting to note here that 47.1 percent individuals identified that they did not experience opposition from any member of the family and society. This is encouraging trend that family and society expressed their willingness to send daughters to attain education in coeducation system but still it needs more resources and strength to spread awareness about girl's education.

\section{IMPACTS OF FINANCIAL LIMITATIONS}

Scarcity of financial resources posed grave consequences on higher education in Pakistan. A large majority with a monthly average income of Rs. 6,000 per family of six members, cannot afford even tuition fees of public sector colleges/universities without financial assistance given by the government or other donor agencies (Leaping Forward, A Report on Higher Education in Pakistan, 2006). Parents are not ready to bear cost of education incurred by their daughters because there are not lot of opportunities of jobs for the female. The share of female labor in 
Pakistan is $1 / 3^{\text {rd }}$ of world average, whereas worldwide percentage of female labors is $50-55$ percent of world and in Pakistan, it is only 20-21 percent. Earning opportunities are less for females. It is believed, despite being educated, females are unlikely to get respectable job in Pakistan and just stay at home being housewives.

Menon identified connection between poverty and low enrollment of school going children in Pakistan (Memon, 2007). According to the 1998 provincial census reports, the school age population of the age group 5-9 years is more than 20 million out of which 11 million (57\%) are out of school. Data reflected that 42 percent of the population living under the illiterate household heads are poor, compared to 21 percent of those living under the literate household heads.

The previous studies reported that dearth of financial resources leads gender discrimination in Pakistan. The household resources are allocated in the favor of sons due to their productive role. Male members of the family are given better education and are equipped with skills to compete for resources in public arena, while female members are imparted domestic skills to be good mothers and wives. The gender discrimination leads to low literacy rates in female members of the society.

Table-18 Impacts of Financial Limitations

\begin{tabular}{lllll}
\hline \hline \multicolumn{1}{c}{ Statement } & $\begin{array}{c}\text { Strongly } \\
\text { Agree }\end{array}$ & $\begin{array}{c}\text { Agre } \\
\text { e }\end{array}$ & $\begin{array}{l}\text { Disagr } \\
\text { ee }\end{array}$ & $\begin{array}{c}\text { Strongly } \\
\text { Disagree }\end{array}$ \\
\hline \hline $\begin{array}{l}\text { High costs of higher education restrict women's to enroll in } \\
\text { higher education }\end{array}$ & 40.6 & 45.1 & 11.3 & 3 \\
$\begin{array}{l}\text { Due to financial limitations parents prefer boy's education over } \\
\text { girls }\end{array}$ & 38.8 & 39.9 & 16.8 & 4.5 \\
$\begin{array}{l}\text { Parents worry to arrange girl's dowry rather than their } \\
\text { education }\end{array}$ & 30.3 & 41.1 & 22 & 6.7 \\
\hline \hline
\end{tabular}

The results of present study are alarming about financial resources dearth. It revealed in table18 that 85.7 percent individuals hold views that higher tuition and lodging expenses in the universities and colleges restrict enrollment of girls from poor and deprived families. World Bank reported that "there has been considerable increase in gender inequality in education in low income countries over the last three decades" (World bank Policy Research Report, 2001). Likewise, the present study reported the gender inequality with 78.7 percent results. It reflect that parents with low income prefer education of male members of the family than female members which further restrict their entry into higher educational institutions. Another factor which pointed out by the study is expensive dowry of the daughters. The 71.4 percent results disclosed that parents are worry to arrange dowry for their daughters rather than their education. In the contemporary era, arranging dowry is hardest ever responsibility of poor parents due to rising costs. The parents prefer to save money for dowry rather than spending it on girl's education because without dowry majority of the girls passed marriage life and failed to get marry which is threatening the social cohesion of the society.

\section{CONCLUSION}

Females in Pakistan are most deprived segment of the society. Even though, in recent years government has introduced various policies to empower them but all went fruitless. Gender inequality has persisted in higher education sector due to various socio-cultural and economic issues. In the above discussion, it has reported that parents are more sensible for their daughter's physical security and threat of sexual harassment stop them to send their daughters in universities and colleges. Similarly lack of higher educational institutions on appropriate distance also obstruct female's entry into higher education. The long distances hamper 
female's higher education which has increased cost of physical and economic expenses. Conservative and outdated local cultural norms and values are also hindering the way of female's higher education. Feudalism and its sub forms Jagirdaari and zamindari system create challenges for female's higher education. The feudal are exploiting peasants and paying lowest wages which even is not sufficient for survival. Thus poverty and deprivation is prevailing which leads to low enrollment of females in higher education. Moreover, gender inequality is also reported in the study.

Pakistani society is still conservative and follow orthodox Islam which view coeducation a biggest threat to society. Parents think that coeducation cause physical damage to their daughters. They also have concerns about their future and think after studying in coeducation system no one will get marry with their daughters which left no choice for girls but to stop higher education. Early marriage is another cause for low rates of females in higher education. Parents prefer to marry their daughters as compared to educate them. They are worry to arrange their dowry which is most expensive now a days. Thus, the present study found that socio-cultural and economic factors have significant impacts on female's higher education in Pakistan and it is dire need of the time to address these challenges in a systematic way.

\section{BIBLIOGRAPHY}

Ali, Manzoor. 2011. "Sexual Harassment: University of Peshawar suspends lecturer." The Express Tribune. May 18. Accessed August 29, 2017. https://tribune.com.pk/story/170748/sexual-harassment-university-of-peshawarsuspends-lecturer/.

Ali, Rana Ejaz Ali Khan \& Karamat. 2005. Bargaining over sons and Daughters Schooling: Probit Analysis of Household Behavior in Pakistan. Working Paper No. 01-05, Islamia University Bahawalpur, Pakistan.

Dempsey, Ernest. 2012. "Sexual Exploitation and Rape Reported in Pakistani University." Digital Journal. February 11. Accessed August 29, 2017. http://www.digitaljournal.com/article/319436.

Ejaz Ashraf, Mohammad Younis \& Hafiz Khurram Shurgeel. 2015. "A Review of Rural Women Education in Pakistan." Science International 27 (1).

Fauzia Maqsood, Sidra Maqsood \& Hammad Raza. 2012. "Getting Higher Education: Is it Really Challenge for Females in Pakistan." Academic Research Journal 2 (3).

Greene, Marry Dallo \& Margaret E. 2011. Addressing Early Marriage of Young and Adolescent Girls. Intraagency Youth Working Group (IYWG).

Gulbaz Ali Khan, Muhammad Azhar \& Syed Asghar Shah. 2011. Causes of Primary School Dropout Among Rural Girls in Pakistan. The Sustainable Development Policy Institute.

Haider, Syed Zubair. 2008. "Challenges in Higher Education: Special Reference to Pakistan and South Asian Developing Countries." Nonpartisan Education Review 4 (2).

Hoodbhoy, Pervez. 2006. "Education in Pakistan-Challenges and Prospects." Center for Public Education. Joseph, Janice. 2015. Sexual Harassmrnt inTertiary Institutions: A Comparative Perspective. TEMIDA.

Junaidi, Ikram. 2014. "Sexual Harassment Allegation rock Quaid-i-Azam University again." Dawn News. June 26. Accessed August 30, 2017. https://www.dawn.com/news/1115223.

Leach, Fiona. 2013. "Corruption as Abuse of Power: Sexual Violence in Educational Institutions." In Transparency International, Global Corruption Report: Education, by S. Linder (EOS) G. Sweeny K. Despota, 88-98. London: Routledge.

2006. Leaping Forward, A Report on Higher Education in Pakistan. Promotion of Education in Pakistan Foundation Inc.

Lina Song, Simon Appleton \& John Knight. 2006. "Why Do Girls in Rural China Have Lower Enrollment?" World Development 34 (9).

Memon, Ghulam Rasool. 2007. "Education in Pakistan: The Key Issues, Problems and the New Challenges." Journal of Management and Social Sciences 3 (1). 
MFEPT. 2017. National Education Policy 2017-2025. Islamabad: Ministry of Federal Education and Professional Training, Government of Pakistan.

Muhammad Irfan Chani, Zahid Pervaiz, Sajjad Ahmed Jan, Amjad Ali \& Amatul R. Chaudhary. 2011. "Poverty, Inflation and Economic Growth: Emperical evidence from Pakistan." World Applied Sciences Journal.

Muhammad Zia Ullah Khan, Sumaira Rehman \& Chaudhry Abdul Rehman. 2015. "Education and Income Inequality in Pakistan." Management and Administrative Sciences Review 4 (1).

Mukhtar, Dr. Khalid Rashid \& Sajid. 2012. "Education in Pakistan: Problems and their Solutions." International Journal of Academic Research in Business and Social Sciences 2 (11).

Naimatullah Hashmi, Muhammad Iqbal Zafar \& Munir Ahmad. 2008. "Cultural Determinants of Female Educational Attainment in Rural Jhang, Punjab, Pakistan." Pak. J. Agri. Sci. 45 (1).

NCHD. 2010. National Commission on Human Development. National Commission for Human Development. http://www.nchd.org.pk .

Pell, Sadia Shaukat \& Anthony William. Winter 2015. "Personal and Social Problems Faced by Women in Higher Education." FWU Journal of Social Sciences 9 (2).

Sen, Amartya. 2001. "Improving Gender Equality in Pakistan, Small Steps to Date, Large Strides Ahead." World Bank. org. Accessed September 3, 2017. http://siteresources.worldbank.org/PAKISTANEXTN/Resources/293051-1146639350561/CGA-Chapter-1.pdf .

Shah, Salman. 2005. "Challenges in the Education Sector in Pakistan." Woodrow Wilson International Center for Scholars.

SPARC. 2004. The State of Pakistan's Children 2003. Islamabad: Society for the Protection of the Rights of the Child. 2001. World bank Policy Research Report. Washington D.C. and New York: World Bank and Oxford University Press.

WWUI. 1978. Sexual Harassment on the Job: Questions and Answers. New York: Working Women United Institute. 